\title{
Nest Boxes Facilitate Local-Scale Conservation of Common Goldeneye (Bucephala clangula) and Bufflehead (Bucephala albeola) in Alberta, Canada
}

\section{Les nichoirs favorisent la conservation à l'échelle locale du Garrot à oil d'or (Bucephala clangula) et du Petit Garrot (Bucephala albeola) en Alberta, Canada}

\author{
$\underline{\text { Robert M. Corrigan }}^{1,2}$, Garry J. Scrimgeour $^{3}$, and Cynthia Paszkowski $^{1}$
}

\begin{abstract}
We tested the general predictions of increased use of nest boxes and positive trends in local populations of Common Goldeneye (Bucephala clangula) and Bufflehead (Bucephala albeola) following the large-scale provision of nest boxes in a study area of central Alberta over a 16-year period. Nest boxes were rapidly occupied, primarily by Common Goldeneye and Bufflehead, but also by European Starling (Sturnus vulgaris). After 5 years of deployment, occupancy of large boxes by Common Goldeneye was $82 \%$ to $90 \%$ and occupancy of small boxes by Bufflehead was $37 \%$ to $58 \%$. Based on a single-stage cluster design, experimental closure of nest boxes resulted in significant reductions in numbers of broods and brood sizes produced by Common Goldeneye and Bufflehead. Occurrence and densities of Common Goldeneye and Bufflehead increased significantly across years following nest box deployment at the local scale, but not at the larger regional scale. Provision of nest boxes may represent a viable strategy for increasing breeding populations of these two waterfowl species on landscapes where large trees and natural cavities are uncommon but wetland density is high.
\end{abstract}

RÉSUMÉ. Nous avons testé les prévisions générales selon lesquelles l'utilisation des nichoirs augmenterait et les populations locales du Garrot à œil d'or (Bucephala clangula) et du Petit Garrot (Bucephala albeola) connaîtraient une hausse à la suite de l'établissement d'un réseau de nichoirs à grande échelle, dans une aire d'étude du centre de l'Alberta, au cours d'une période de 16 ans. Les nichoirs ont été rapidement occupés par le Garrot à œil d'or et le Petit Garrot, mais aussi par l'Étourneau sansonnet (Sturnus vulgaris). Cinq ans après l'établissement du réseau, le taux d'occupation des nichoirs de grande dimension par le Garrot à œil d'or était de 82 à $90 \%$ et le taux d'occupation des nichoirs de petite dimension par le Petit Garrot, de 37 à $58 \%$. L'analyse fondée sur un échantillonnage en grappes à un degré a montré que la fermeture expérimentale de l'entrée des nichoirs a entraîné une réduction importante du nombre de couvées et de la taille des couvées produites par les deux espèces de canards. La présence et la densité du Garrot à œil d'or et du Petit Garrot ont augmenté de façon significative à l'échelle locale au cours des années suivant l'établissement du réseau de nichoirs, mais pas à l'échelle régionale. L'installation de nichoirs pourrait s'avérer une stratégie durable pour favoriser l'accroissement des populations nicheuses de ces deux espèces dans les paysages où les arbres de gros diamètre et les cavités naturelles sont rares, mais où la densité de milieux humides est élevée.

Key Words: Alberta; bufflehead; common goldeneye; nest boxes; nest box limitation

${ }^{1}$ Department of Biological Sciences, University of Alberta, Edmonton, Alberta, ${ }^{2}$ Fish and Wildlife Division, Alberta Sustainable Resource Development, Edmonton, Alberta, ${ }^{3}$ Alberta Conservation Association, Edmonton, Alberta

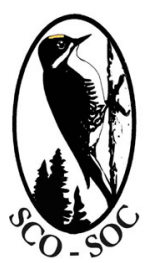

Sponsored by the Society of Canadian Ornithologists and Bird Studies Canada Parrainée par la Société des ornithologistes du Canada et Études d'oiseaux Canada

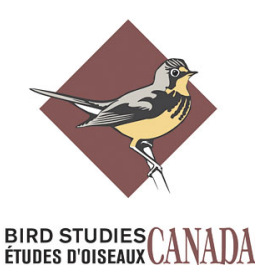




\section{INTRODUCTION}

Biologists apply a broad suite of conservation prescriptions to compensate for human-induced declines in habitat quality. Nest boxes are widely used to enhance populations of cavity-nesting species including waterfowl (Savard 1988, Newton 1994, Pöysä and Pöysä 2002, Savard and Robert 2007), passerines (Nilsson 2008), sea birds (Bolton et al. 2004), and marsupials (Lindenmayer et al. 2009). The effectiveness of nest boxes is determined by a variety of factors including design (GarcíaNavas et al. 2008), adjacency to key resources (Aitken and Martin 2004), predation (Brightsmith 2005), nest defense behavior (Rosvall 2008), reproductive output of targeted species (Mátics et al. 2008), and the extent that territoriality limits density (Duckworth 2006).

The prairie pothole region is the most important in North America for breeding waterfowl. Although this region contains $10 \%$ of all suitable breeding habitat, it accounts for $>50 \%$ of annual continental waterfowl production (Batt et al. 1989). Loss of wetlands in the prairie pothole region has conservatively resulted in a 50\% decline in habitat since European settlement (Dahl 1990). In Alberta, a survey of 398 waterbodies in the Prairie Pothole region also found that $80 \%$ of sites had reduced natural riparian areas and $32 \%$ had been completely cleared of woody vegetation between 1945 to 1974 (Merriam 1978). For secondary cavity-nesters, such as waterfowl, direct effects of habitat loss are compounded by accompanying declines in populations of species that excavate cavities, such as large woodpeckers (Vaillancourt et al. 2009).

In 1989, a program began to deploy nest boxes across the Buffalo Lake Moraine of central Alberta to address a perceived lack of natural nesting cavities for Common Goldeneye (Bucephala clangula) and Bufflehead (Bucephala albeola; Potter 2004). After 10 years, census data suggested local scale increases in densities of both species, whereas breeding densities of other waterfowl had either remained stable or declined (Murphy et al. 2004). The extent that population increases in Bucephala species may be related to the provision of nest boxes was difficult to assess in part because increases in density of Bucephala could have resulted from larger scale increases, e.g., in North America, in the abundance of these species.

The present study had three objectives. First, we quantified temporal patterns in occupancy of nest boxes by Common Goldeneye and Bufflehead in the Buffalo Lake Moraine between 1989 to 2005. Second, we performed an experiment to determine whether the two species were limited by the availability of nest sites. Third, we quantified densities of Common Goldeneye and Bufflehead to evaluate evidence that the provision of nest boxes over the 16-year period influenced population sizes at the local scale, and compared these patterns to those of other waterfowl species. We predicted that (1) nest boxes would be rapidly occupied and that use by Common Goldeneye and Bufflehead would increase though time, (2) closure of nest boxes would not influence occupancy of wetlands by pairs of adult Common Goldeneye and Bufflehead because of high levels of nest site fidelity (e.g., Savard and Eadie 1989, Gauthier 1990) but would reduce numbers of broods, (3) reductions in numbers of broods because of nest box closure would be most pronounced for Common Goldeneye, who require larger, rarer cavities for nesting, compared with Bufflehead, and (4) deployment of nest boxes would coincide with local but not regional scale increases in occurrence and density of Common Goldeneye and Bufflehead, consistent with the hypothesis that deployment of nest boxes augments population sizes of both species on the Buffalo Lake moraine.

\section{METHODS}

\section{Study area}

The Buffalo Lake Moraine $\left(1300 \mathrm{~km}^{2}\right)$ is located in the aspen parkland ecoregion of central Alberta, Canada (Fig. 1) and represents a highly homogenous knob and kettle topography of shallow water holding depressions. Prior to European settlement, it comprised a mosaic of grassland and groves of drought tolerant trees. Mean annual precipitation ranges between 400-500 $\mathrm{mm}$ (Strong and Leggat 1992) with open water on wetlands between April to October. The moraine can support densities of wetlands exceeding 20 per $\mathrm{km}^{2}$ set within intensive and semi-intensive agricultural activities, primarily livestock grazing and to a lesser extent, cropping. Riparian zones adjacent to wetlands comprise narrow bands of aspen (Populus tremuloides), balsam poplar (Populus balsamifera), paper birch (Betula papyrifera), and willow (Salix spp.; Bailey and Wroe 1974). Shrubs and young trees dominate, with low densities of large trees and snags to provide breeding sites for cavity-nesters. The age and size of riparian forests was controlled historically by 
Fig. 1. Location of Buffalo Lake Moraine and Stratum 26 (A), and locations and spatial extent of clusters of wetlands where nest boxes were open (dashed lines) or closed (solid lines) for use by Common Goldeneye, Bucephala clangula (B), and Buffleheads, Bucephala albeola (C), in central Alberta, Canada in 2004. All nest boxes were open for occupancy by Common Goldeneye and Bufflehead in 2005.

A
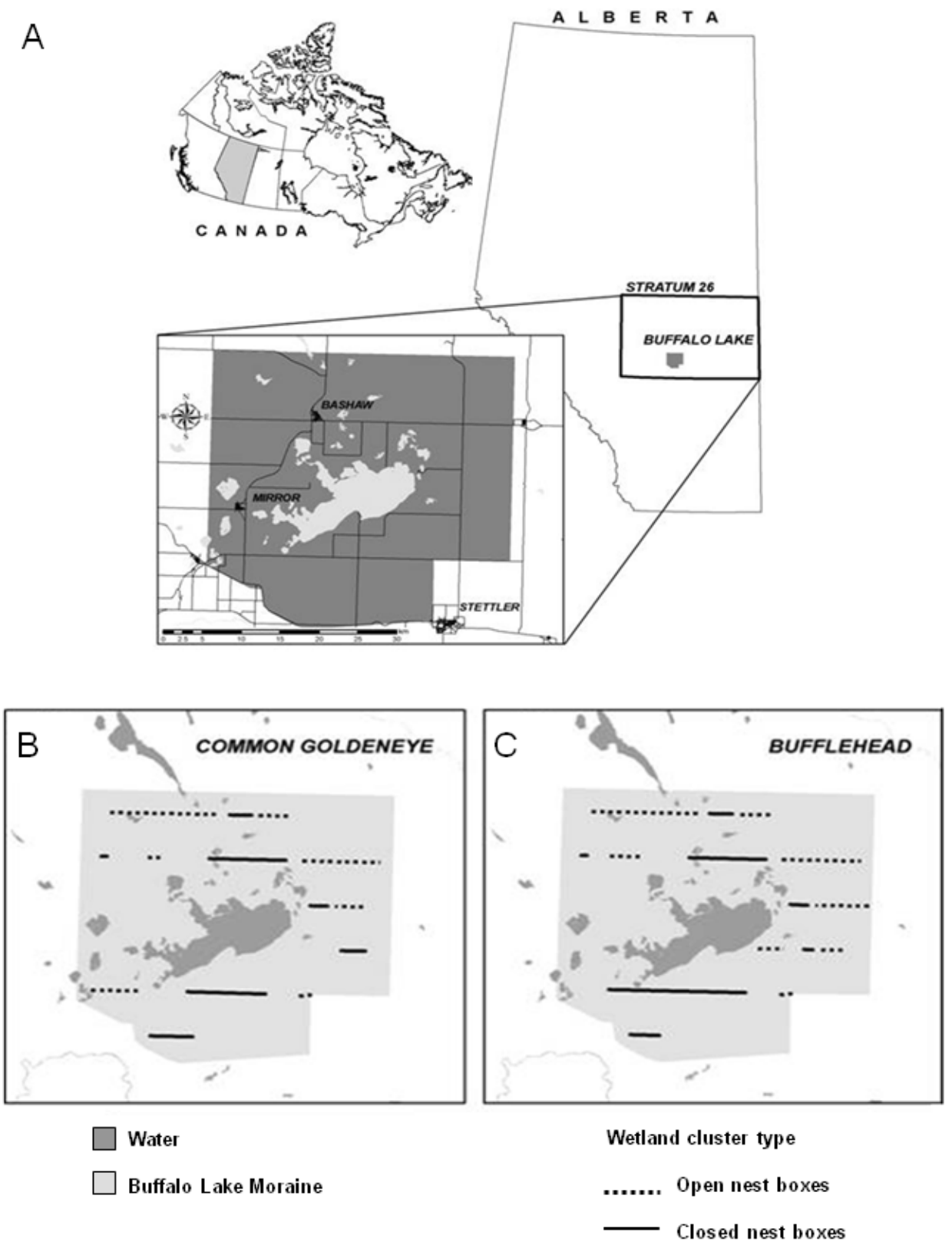

Water

Buffalo Lake Moraine

Closed nest boxes

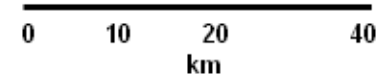


wildlife and drought (Hogg et al. 2005). Recent influences include clearing for agriculture, livestock grazing, prescribed fires to remove brush and snags (Hood and Bayley 2003, Stavne 2005), and a systematic $3.2 \mathrm{~km} \times 1.61 \mathrm{~km}$ network of roads. Commercial forest harvesting is absent in the aspen parkland.

\section{Temporal patterns in nest box occupancy}

Nest boxes were first deployed on the Buffalo Lake Moraine for Common Goldeneye and Bufflehead in 1989 and 1991, respectively (Potter 2004) on semipermanent to permanent wetlands, i.e., Type III to Type V wetlands (Stewart and Kantrud 1971) of 0.02-97.0 ha, and maximum depths of 2-3 $\mathrm{m}$. The majority of these wetlands provide open water conditions from spring (April) to late fall (October). Numbers of nest boxes between 1989 to 2003 ranged from 185-279 for Common Goldeneye and 38-80 for Bufflehead. Lower numbers of small (2004: $\mathrm{n}=33$, 2005: $\mathrm{n}=38$ ) and large nest (2004: $\mathrm{n}=51,2005: \mathrm{n}=66$ ) boxes were available for occupancy in 2004 and 2005 as part of the nest box manipulation.

Nest boxes comprised rectangular wooden boxes (height $\mathrm{x}$ width $\mathrm{x}$ depth: Common Goldeneye boxes $=80 \mathrm{~cm} \times 27 \mathrm{~cm} \times 65 \mathrm{~cm}$; Bufflehead boxes $=60$ $\mathrm{cm} \times 18 \mathrm{~cm} \times 45 \mathrm{~cm}$ ) with oval entrance holes (Common Goldeneye: $8 \mathrm{~cm}$ x $10 \mathrm{~cm}$, Bufflehead: 7 $\mathrm{cm} \times 8 \mathrm{~cm}$ ) located $15 \mathrm{~cm}$ below the top of the box (Potter 2004). Boxes had a removable side to facilitate inspection to determine occupancy. Boxes were attached to large (diameter at breast height $>20$ $\mathrm{cm}$ ) live trees within riparian zones so that entrance holes were $\geq 1.3 \mathrm{~m}$ above the ground level. Small nest boxes were attached to about $20 \%$ to $35 \%$ of all trees that received large nest boxes. In a few cases, two sets of nest boxes, i.e., one large and one small, or two large nest boxes were installed on an individual tree adjacent to large wetlands and sets were separated by $\geq 75 \mathrm{~m}$ to reduce interactions between pairs. Following installation, wood chips were added to boxes to form a $15 \mathrm{~cm}$ base of nesting material.

As part of a nest box program (Potter 2004), nest box occupancy between 1989 and 2003 was determined by visually inspecting nest boxes for the presence of egg shells, yolk sacs, and unhatched eggs following fledging, i.e., fall -winter. Because evidence of nest box use was removed following inspection, the presence of eggs, egg shells, and yolk sacs the following fall-winter reflected use in the prior summer and not use in earlier years. Delays in assessing nest box use to the fall-winter could potentially underestimate estimates of nest box occupancy because of predation events that remove evidence of use. Because the predominant nest box predators in our study area, the raccoon (Procyon lotor) and American Mink (Neovison vison), do not totally remove all egg materials ( $\mathrm{R}$. Corrigan, unpublished data), it is unlikely that they influence estimates of occupancy. In 2004 and 2005, we determined occupancy of boxes based on the presence of eggs in the spring. Although methods to establish nest box occupancy differed among years, i.e., 1989-2004 vs. 2004-2005, both provide high levels of certainty of use. Determining nest box use in the spring of 2004 and 2005 also allowed us to evaluate the effects of closure of nest boxes on clutch sizes. We used binoculars to document the use by other species, such as European Starling (Sturnus vulgaris) and red squirrel (Tamiasciurus hudsonicus), because they influence occupancy rates by Bufflehead and to a lesser extent Common Goldeneye.

\section{Nest box manipulation}

We conducted a nest box manipulation, using a single-stage cluster design (Hayek and Buzas 1997), in 2004-2005 to test the hypothesis that Common Goldeneye and Bufflehead in the Buffalo Lake Moraine are limited by the availability of nesting cavities. Single-stage cluster designs assume that individual clusters do not overlap so that each study organism counted can only be present in one cluster (Hayek and Buzas 1997). We fulfilled this assumption by ensuring that the alternating clusters of wetlands were separated by $\geq 800 \mathrm{~m}$ since Common Goldeneye seldom move broods between wetlands beyond this distance (Wayland and McNicol 1994). We closed nest boxes in winterspring 2003-2004 by wrapping them with brown burlap fabric and covering entrance holes with plywood. In winter-spring 2004-2005, we reopened boxes closed the previous year, thus all nest boxes were again available for occupancy in 2005.

Nest boxes used in the experiment represented a subset of those installed between 1989 to 2003 (Allen 1989). We divided six road-based transects, used to survey ponds in the moraine since 1989, into alternating clusters of six to 34 wetlands along 
0.73-17.1 km long segments, in which existing boxes remained open for the 2004 breeding season or were closed (Fig. 1). Transects were established by Allen (1989) to monitor waterfowl populations in the moraine. Nest boxes were attached to large trees (diameter at breast height $>20 \mathrm{~cm}$ ) located within riparian zones of more permanent, Class III to Class V, wetlands.

Individual clusters encompassed wetlands within $200 \mathrm{~m}$ north or south of the roadways. The most northern and western cluster of wetlands was randomly assigned to the open nest box treatment with subsequent clusters of wetlands reflecting alternating treatments of closed and open clusters (Fig. 1B, C). We used a nearest neighborhood spatial analysis tool to separate open vs. closed clusters of wetlands. The transition from the first open cluster to the first closed cluster occurred when our spatial analyses revealed that the nearest neighbor wetland exceeded $800 \mathrm{~m}$. Subsequent transitions of closed to open clusters were established when GIS queries revealed natural breaks in the distances between wetlands were at least $800 \mathrm{~m}$ and when the cluster included at least six wetlands. We repeated this approach to establish 14 clusters of wetlands for Bufflehead, i.e., seven open and seven closed, and 15 clusters of wetlands for Common Goldeneye reflecting seven open and eight closed clusters (Fig $1 \mathrm{~B}, \mathrm{C})$. Because our primary concern was to establish clusters of wetlands that were at least 800 $\mathrm{m}$ apart, lengths of clusters ranged from 0.73 to 17.1 $\mathrm{km}$, but did not differ $(\mathrm{P}=0.57, \mathrm{P}=0.71$ for Common Goldeneye and Bufflehead clusters, respectively) between the open vs. closed cluster treatments (Table 1).

We determined if closure of nest boxes affected (1) numbers of pairs, (2) numbers of broods, and (3) brood sizes produced by Common Goldeneye and Bufflehead by visually surveying clusters every two to four days in June-July 2004. This period encompassed hatching dates for Common Goldeneye (June 17) and Bufflehead (June 26) in the moraine (Murphy et al. 2004). We surveyed once in August to record late-hatching broods. Surveys commenced at sunrise and concluded at noon or when conditions limited visibility.

\section{Temporal patterns in densities of Common Goldeneye and Bufflehead}

If nest box deployment resulted in local enhancement of population size, we predicted positive relationships between annual estimates of population density of Common Goldeneye and Bufflehead in the Buffalo Lake Moraine and "year" as use of boxes and duck numbers increased through time. Increases in the occurrence and density of both species coinciding with deployment of nest boxes over a 16-year period is consistent with the hypothesis that Common Goldeneye and Bufflehead are limited by the availability of natural nesting cavities, and that deployment of boxes may contribute to population gains. However, localscale changes in waterfowl populations can reflect larger scale, often regional or continental, shifts in population size. We evaluated whether possible increases in the occurrence and density of Common Goldeneye and Bufflehead reflected larger scale increases in population size by testing for relations between population size of Common Goldeneye and Bufflehead with year and wetland density at the larger regional scale of Stratum $26\left(90,300 \mathrm{~km}^{2}\right)$ of the United States Fish and Wildlife Service and Canadian Wildlife Service continental waterfowl surveys. If positive effects of nest box deployment were local, we expected no relationships or weak relationships between annual estimates of population density of Common Goldeneye and Bufflehead with year when measured at the larger regional scale.

Occurrence and breeding densities of Common Goldeneye and Bufflehead, and six other common waterfowl species in the Buffalo Lake Moraine were estimated along the six east-west road transects described in connection with the nest box manipulation. Transects extended $200 \mathrm{~m}$ north and south on either side of the road. Total transect length was $159.3 \mathrm{~km}$ and encompassed $64.1 \mathrm{~km}^{2}$. Two breeding waterfowl surveys were conducted every second year between 1989 to 2003. The first survey occurred in the first two weeks of May with the second survey completed during the first week of June. An additional survey was conducted in 2004 for a total of nine surveys over the 16-year study period. Annual estimates of breeding density were based on the greater of the two surveys. Survey procedures were as described previously. During May surveys, wetlands were classified regarding 
Table 1. Mean $( \pm S E)$ cluster length and habitat characteristics of wetlands where nest boxes were open or closed to occupancy by Common Goldeneye (Bucephala clangula) and Bufflehead (Bucephala albeola) in the Buffalo Lake Moraine, Alberta in 2004. Analyses were completed using Wilcoxon Rank Sum test (z scores) using seven open and seven closed clusters for Common Goldeneye, and eight (open) and seven (closed) clusters for Bufflehead.

\begin{tabular}{|c|c|c|c|c|c|}
\hline \multirow[t]{2}{*}{ Species } & \multirow[t]{2}{*}{ Habitat characteristic } & \multicolumn{2}{|c|}{ Nest box cluster type } & \multicolumn{2}{|c|}{ Wilcoxon rank tests } \\
\hline & & Open & Closed & $\mathrm{Z}$ & $\mathrm{P}$ \\
\hline \multirow[t]{6}{*}{ Common Goldeneye } & Cluster length $(\mathrm{km})$ & $6.00+1.71$ & $4.75+1.40$ & 0.57 & 0.57 \\
\hline & Deciduous forest cover (ha) & $7.89 \pm 5.34$ & $9.55 \pm 5.22$ & 0.89 & 0.37 \\
\hline & Deciduous forest perimeter $(\mathrm{km})$ & $4.51 \pm 2.69$ & $5.39 \pm 2.13$ & 1.15 & 0.25 \\
\hline & Wetlands (ha) & $24.28 \pm 5.26$ & $19.09 \pm 6.15$ & 0.51 & 0.61 \\
\hline & Wetlands perimeter $(\mathrm{km})$ & $13.16 \pm 3.37$ & $14.40 \pm 4.77$ & 0.13 & 0.90 \\
\hline & Number of Class III - V wetlands & $15.14 \pm 2.82$ & $15.43 \pm 3.54$ & 0.17 & 0.87 \\
\hline \multirow[t]{6}{*}{ Bufflehead } & Cluster length $(\mathrm{km})$ & $4.37+1.03$ & $5.28+2.25$ & 0.36 & 0.71 \\
\hline & Deciduous forest cover (ha) & $6.13 \pm 2.28$ & $13.98 \pm 6.21$ & 0.75 & 0.46 \\
\hline & Deciduous forest perimeter $(\mathrm{km})$ & $3.64 \pm 1.18$ & $7.24 \pm 2.59$ & 0.87 & 0.39 \\
\hline & Wetlands (ha) & $22.07 \pm 5.08$ & $19.02 \pm 7.23$ & 1.01 & 0.31 \\
\hline & Wetlands perimeter $(\mathrm{km})$ & $12.71 \pm 3.10$ & $14.2 \pm 5.64$ & 0.41 & 0.69 \\
\hline & Number of Class III - V wetlands & $15.25 \pm 2.53$ & $13.57 \pm 3.96$ & 1.19 & 0.24 \\
\hline
\end{tabular}

permanence (Class I-V; Stewart and Kantrud 1971). We quantified densities of largely permanent (Class III to Class V) wetlands (number $/ \mathrm{km}^{2}$ ) for each survey year by dividing the total number of wetlands counted within transects by the transect study area $\left(64.1 \mathrm{~km}^{2}\right)$. We expressed availability of wetland habitat based on density rather than total wetland area because density (1) is highly robust to annual and within seasonal variance in precipitation that alters the spatial, i.e., surface area, extent of wetlands, and (2) it allowed us to assess annual wetland abundance at the larger spatial scales of Strata 26, where satellite imagery required to estimate the spatial extent of wetlands is available at only 5 to 10 year intervals.

At the larger regional scale, we used density estimates for Common Goldeneye and Bufflehead based on data collected by aerial surveys of Stratum 26 by the United States Fish and Wildlife Service (see Bellrose 1980, United States Fish and Wildlife Service and Canadian Wildlife Service 1987).

\section{Statistical analysis}

Use and temporal variation in the occupancy of nest boxes

We used a $2 \times 2$ chi-square contingency test to compare occupancy rates by Common Goldeneye in 2005 of nest boxes that had been open in 2004 vs. closed in 2004 using SPSS (SPSS 2007). High levels of reoccupancy of boxes in 2005 would provide further evidence of nest site limitation. 
We used correlation analyses to examine relations between percent occupancy of nest boxes by Common Goldeneye and Bufflehead vs. European Starling. We used linear regression to evaluate relations between percent of nest boxes occupied by Common Goldeneye and Bufflehead vs. the number of boxes available in each year. We also used regression to evaluate relations between percent of nest boxes occupied by Common Goldeneye and Bufflehead vs. densities of Common Goldeneye and Bufflehead. Positive relations between occupancy and bird density suggest that new birds are entering the population and are using nest boxes, whereas the absence of these positive relations suggests a shift in the use of natural cavities to nest boxes. Where required, data were transformed prior to analyses to fulfill assumptions of normality and homogeneity of variances.

\section{Nest box manipulation}

We tested the hypotheses that the mean (1) number of pairs per cluster, (2) number of broods per cluster, and (3) brood size for each cluster for Common Goldeneye and Bufflehead were unaffected by cluster type, i.e., open vs. closed boxes, using t-tests, or Wilcoxon rank sum tests where assumptions of t-tests could not be satisfied, with wetland cluster as the unit of replication. Although the use of the cluster design increases the independence of the open vs. closed nest box treatment, it results in lower samples sizes and thus we interpreted statistical significance at the $\mathrm{P}=0.10$ level.

We queried for habitat attribute data from a native parkland vegetation inventory (Bjorge 2003) spatial geodatabase in ArcGIS and these data were used to compare habitat attributes of wetlands within open and closed clusters to ensure that responses to the manipulation reflected the treatment and not differences in habitat features of wetlands within clusters. We used Wilcoxon rank-sum tests to evaluate differences between the two cluster types in (1) cluster lengths, (2) area in deciduous forest (hectares), (3) wetland perimeter in deciduous forest (kilometers), (4) total area of wetlands (hectares), (5) total length of wetland shoreline (kilometers), and (6) number of more permanent wetlands.

\section{Temporal patterns in population densities of Common Goldeneye and Bufflehead}

To test for relations between densities of Common Goldeneye and Bufflehead and year (1989 to 2004) and wetland density at both the local scale (Buffalo Lake Moraine) and regional scale (Stratum 26), we conducted generalized linear model regressions using GLM in R version 2.11.1 (R Project for Statistical Computing, http://www.r-project.org). We constructed three models to represent what we suspected to be important in affecting Common Goldeneye and Bufflehead density in both local (Buffalo Lake Moraine) and regional (Stratum 26) scales. Models included "year", "wetland density", and "year + wetland density." We included "year" as a candidate variable because population sizes of Common Goldeneye and Bufflehead should increase over the 16-year study period if the availability of nest boxes and their adoption by females supplemented reproductive output from natural cavities. We expected that "year" would feature prominently among the most parsimonious regression models of Common Goldeneye and Bufflehead density at the local scale, but not at the larger spatial scale of Stratum 26, and that the model coefficients for "year" would be more strongly positive in the local-scale models compared to models derived for Stratum 26. We included "wetland density" as a candidate variable because it is a measure of the total amount of habitat available for breeding and is dependent upon local weather conditions that influence the spatial extent and depth of wetlands at both the local and regional scales. We used Akaike's Information Criterion for small sample sizes $\left(\mathrm{AIC}_{\mathrm{c}}\right)$ to rank models within each set (Burnham and Anderson 2002). Initial analyses showed that Akaike weights $\left(\mathrm{w}_{\mathrm{i}}\right)$ were low $(<0.90)$ and that model averaging would be required to obtain a model-averaged parameter estimates and unconditional standard errors (Burnham and Anderson 2002).

Lastly, we compared the occurrence and density of Common Goldeneye and Bufflehead with patterns in occurrence and abundance of six other representative waterfowl species between 1989-2004 (occurrence) and 1989-2003 (density) on surveyed wetlands on the moraine (1275-1444 sites depending on water conditions).

\section{RESULTS}

\section{Use and temporal variation in the occupancy of nest boxes}

Nest boxes were rapidly occupied by Common Goldeneye, Bufflehead, European Starling, and to 
a lesser extent red squirrels. Combined, these four species occupied $82 \%$ to $100 \%$ of large boxes and $53 \%$ to $94 \%$ of small boxes within a few years of deployment (Fig. 2A). Occupancy of large nest boxes by Common Goldeneye (185 to 271 boxes) and small boxes by Bufflehead (40 to 80 boxes) increased from about $10 \%$ to $85 \%$ and $8 \%$ to $31 \%$, respectively, during the first 5 years following deployment (Fig. 2B). Thereafter, occupancy ranged between $82 \%$ to $90 \%$ and $37 \%$ to $58 \%$ for the two species, respectively. Preliminary linear regression showed that percent occupancy of large and small boxes by Common Goldeneye and Bufflehead was unrelated to the number of boxes deployed in any one year $(\mathrm{P}=0.86, \mathrm{P}=0.79$, respectively).

In 2005, we assessed the occupancy by Common Goldeneye of 32 large nest boxes that had remained open during the 2004 breeding season and 34 that were closed during the 2004 breeding season. Of the 32 boxes that were open in 2004, 28 were subsequently occupied in $2005(87.5 \%)$. Similarly, 26 of $34(76.5 \%)$ boxes that were closed in 2004 were occupied in 2005. Occupancy of boxes in 2005 that were closed in 2004 did not differ significantly (Chi square $=1.4, \mathrm{P}=0.25$ ) from boxes that were open both years.

The majority of nest boxes that were not used by Bufflehead or Common Goldeneye were occupied by European Starlings (Fig. 2C). Use of the large boxes by European Starlings decreased from $78 \%$ in 1989 to $26 \%$ in 1992 , i.e., three years after deployment, and remained low $(<10 \%)$ in the following 10 years. Use of small boxes by European Starlings declined from $73 \%$ in 1991 to $41 \%$ in 1993, but remained relatively high (annual occupancy $=18 \%$ to $47 \%$ ) in subsequent years (Fig. $2 \mathrm{C})$. Correlation analyses showed that the percent occupancy of nest boxes by European Starlings was negatively related to occupancy by Common Goldeneye $(r=-0.96)$ and Bufflehead $(r=-0.75$; Fig. 3).

\section{Nest box manipulation}

Mean numbers of pairs of Common Goldeneye and Bufflehead did not differ significantly $(\mathrm{P}=0.87, \mathrm{P}$ $=0.75$ ) between clusters of wetlands with open nest boxes vs. closed boxes (Fig. 4). Mean number of broods and brood sizes for Common Goldeneye and Bufflehead on clusters of wetlands with open boxes were significantly greater than on clusters with closed boxes (Fig. 4). In relative terms, closure of nest boxes resulted in proportionately higher reductions in numbers of broods and brood sizes for Common Goldeneye (10 and 9-fold reductions, respectively) compared to the 3 -fold reduction in numbers of broods and brood sizes of Bufflehead (Fig. 4).

Habitat comparisons showed that open and closed wetlands clusters contained similar surface areas covered by deciduous forest and wetlands, lengths of wetland shoreline, perimeters of deciduous forest, and numbers of more permanent, Class III to Class V, wetlands (Table 1). Thus, differences in the number and sizes of broods for both species were likely due to the experimental manipulation.

Percent of nest boxes occupied by Common Goldeneye and Bufflehead were positively related to densities of Common Goldeneye (Percent occupancy $=18.9+19.8$ density $\left(\mathrm{F}_{(1,5)}=10.3, \mathrm{R}^{2}=\right.$ $0.67, \mathrm{P}=0.024$ ) and Bufflehead (Percent occupancy $=-39.3+21.4$ density $\left(F_{(1,5)}=21.2, \mathrm{R}^{2}=0.81, \mathrm{P}=\right.$ 0.006). This suggests that new birds entered the Buffalo Lake Moraine between 1989 and 2004 and used nest boxes.

\section{Temporal patterns in population densities of Common Goldeneye and Bufflehead}

Between 1989 to 2004 densities (individuals / $\mathrm{km}^{2}$ ) of Common Goldeneye and Bufflehead in the Buffalo Lake Moraine ranged from 0.88 to 4.48 and 2.1 to 4.64 and from 0.02 to 0.34 and 0.35 to 0.89 at the regional scale of Stratum 26, respectively. During the same period, densities of wetlands ranged from 5.3 to 20.2 wetlands $/ \mathrm{km}^{2}$ in the Buffalo Lake Moraine and from 2.5 to 7.2 wetlands $/ \mathrm{km}^{2}$ at the larger regional scale of Stratum 26.

With the possible exception of the local scale models for Common Goldeneye (Table 2) Akaike weights $\left(\mathrm{w}_{\mathrm{i}}\right)$ were divided among models, with no one apparent most parsimonious model. Modelaveraging resulted in estimates of parameters and unconditional standard error for each model set (Table 3). These data show that density of Common Goldeneye and Bufflehead were positively and most strongly related to year at the local-scale (coefficients $=0.24 \pm 0.06$ and $0.130 \pm 0.049$ ) compared with that at the larger spatial scale of Stratum 26 (coefficients $=0.005 \pm 0.008$ and 0.008 
Fig. 2. Temporal patterns in percent occupancy of small and large nest boxes by all species combined (A), Common Goldeneye, Bucephala clangula, and Bufflehead, Bucephala albeola (B), and European starlings, Sturnus vulgaris (C) in the Buffalo Lake Moraine between 1989 to 2005 in central Alberta. Numbers in plot A reflect numbers of nest boxes, whereas numbers in plot $\mathrm{C}$ reflect initial study years when occupancy by European Starlings was highest.

A) All species combined
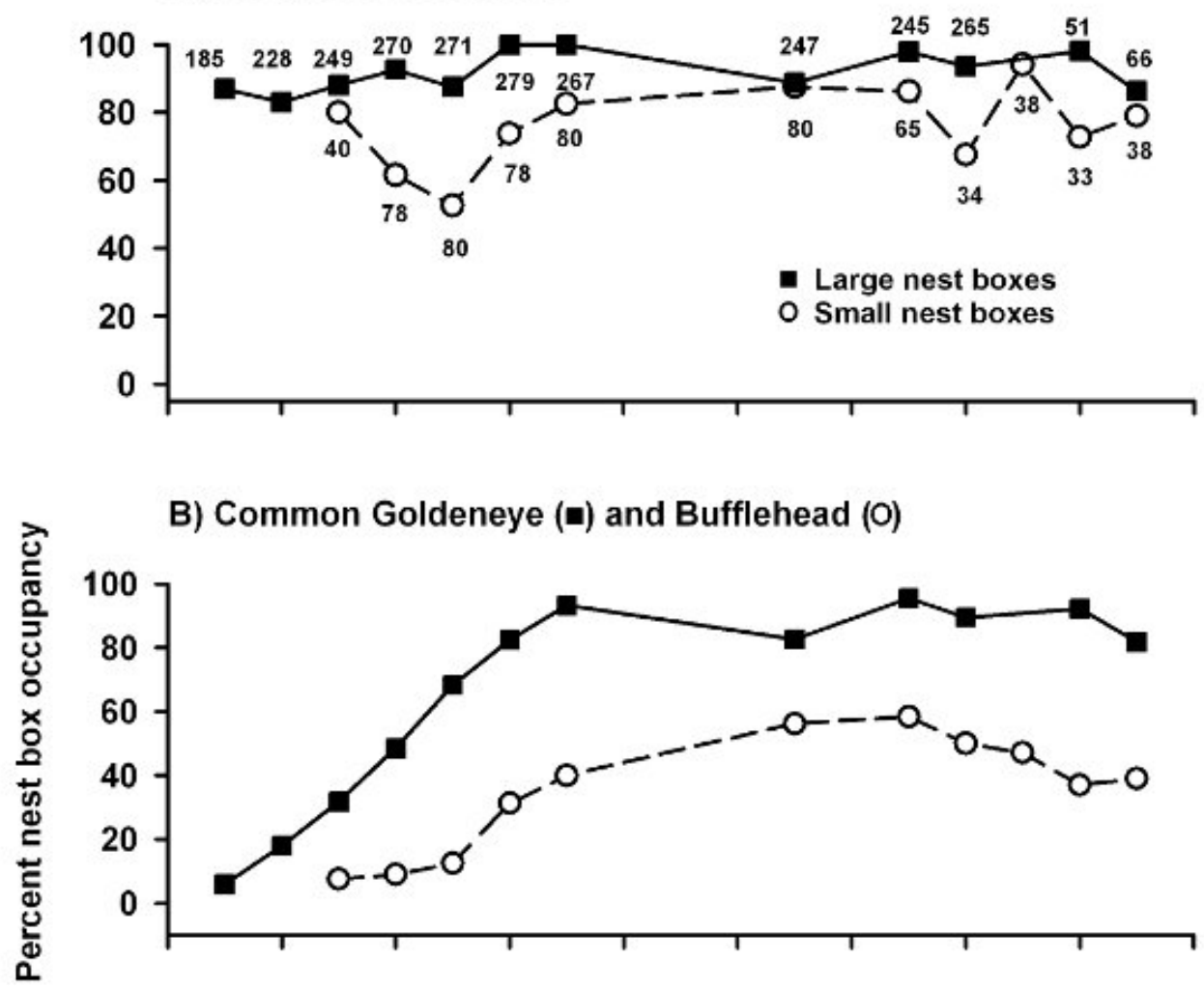

C) European Starlings

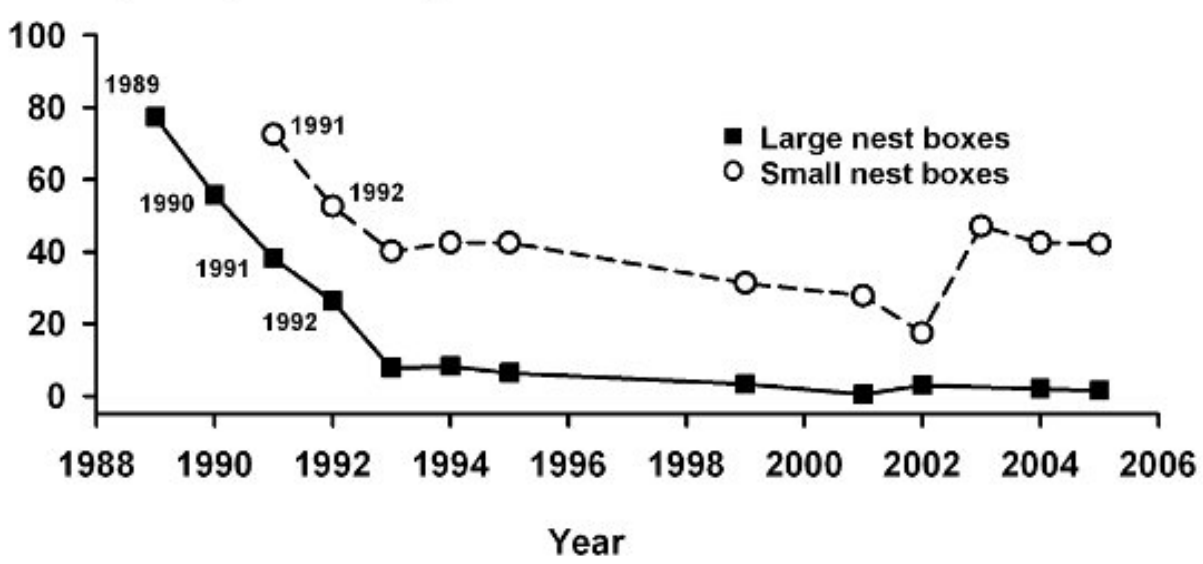


Fig. 3. Relations between occupancy of nest boxes by European Starlings, Sturnus vulgaris, and Common Goldeneye, Bucephala clangula, in large nest boxes (A) and Bufflehead, Bucephala albeola, (B) in small nest boxes deployed in the Buffalo Lake Moraine, south-central Alberta. Numbers accompanying symbols reflect study years.

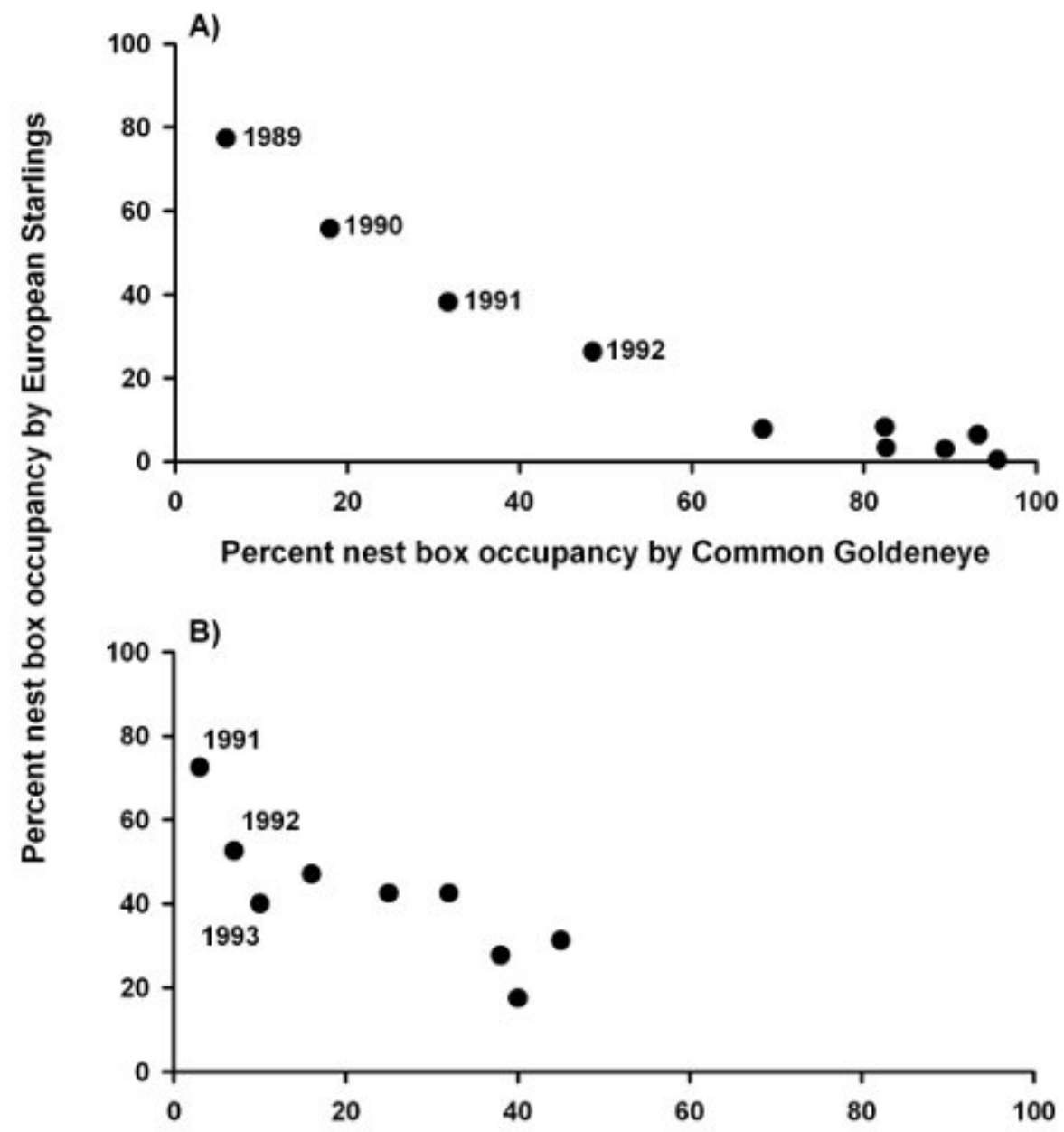

Percent nest box occupancy by Bufflehead

$\pm 0.009)$. These results suggest that population gains of Common Goldeneye and Bufflehead, coinciding with 16 years of next box deployment, is unlikely due to larger scale population increases of the two species at the regional scale. Densities of Bufflehead were positively related to wetland density at both the local and regional scales and for Common Goldeneye at the local scale, but not at the regional scale (Table 3).
Positive local trends for populations of Common Goldeneye and Bufflehead between 1989 and 2003 were also reflected in patterns of occurrence and density of the two species on $>1250$ wetlands surveyed along six transects on the moraine, especially relative to other common waterfowl (Fig. 5). Occurrence frequency of dabbling duck species, e.g., Mallard (Anas platyrhynchos) and Bluewinged Teal (Anas discors), decreased from $45 \%$ to $30 \%$ of wetlands, and diving ducks, e.g., Lesser 
Fig. 4. Comparison of mean ( \pm SE) number of pairs $(A)$, broods $(B)$, and brood size $(C)$ of Common Goldeneye (Bucephala clangula) and Bufflehead (Bucephala albeola) in 2004 from clusters of wetlands where nest boxes were open (black fill) or closed (white) to occupancy in the Buffalo Lake Moraine, 2004. P-values reflect outcomes of t-tests for the effects of the nest box closure treatment.

Common Goldeneye

Bufflehead

A) Number of pairs
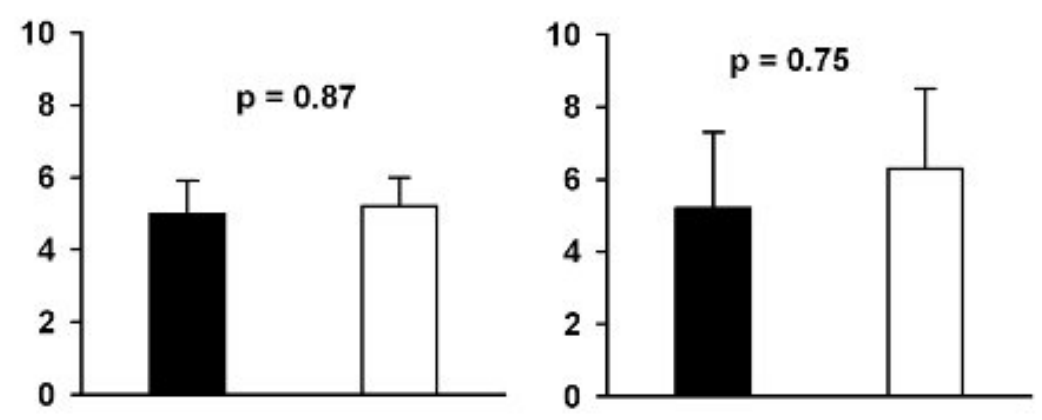

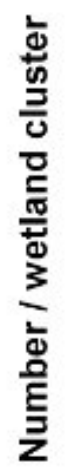

B) Number of broods
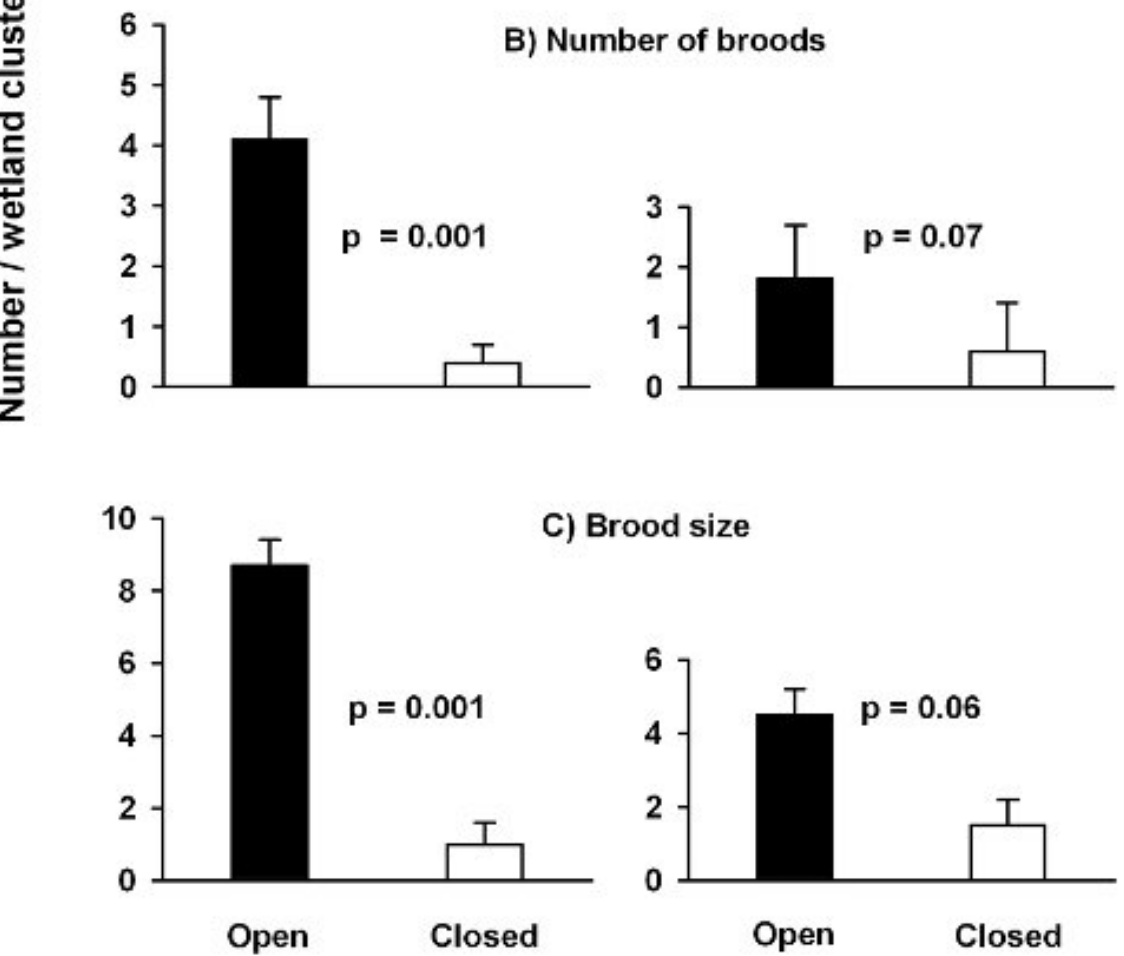

Nest box availability 
Table 2. Summary of regression models relating densities of nesting pairs of Common Goldeneye (Bucephala clangula) and Bufflehead (Bucephala albeola) to year and wetland density. $\Delta \mathrm{i}=\mathrm{AICc}, \mathrm{i}-\mathrm{AICc}$, wi= Akaike weight.

\begin{tabular}{|c|c|c|c|c|c|}
\hline Species & $\mathrm{K}$ & $\mathrm{AIC}_{\mathrm{c}}$ & $\Delta \mathrm{i}$ & $w_{i}$ & Rank \\
\hline \multicolumn{6}{|l|}{ Common Goldeneye } \\
\hline \multicolumn{6}{|l|}{ Local scale models } \\
\hline year + wetland density & 4 & 25.6 & 0 & 0.83 & 1 \\
\hline year & 3 & 28.8 & 3.2 & 0.17 & 2 \\
\hline wetland density & 3 & 36.6 & 11.0 & 0.003 & 3 \\
\hline \multicolumn{6}{|l|}{ Regional scale models } \\
\hline wetland density & 3 & -10.6 & 0 & 0.46 & 1 \\
\hline year & 3 & -10.0 & 0.7 & 0.33 & 2 \\
\hline year + wetland density & 4 & -9.1 & 1.6 & 0.21 & 3 \\
\hline \multicolumn{6}{|l|}{ Bufflehead } \\
\hline \multicolumn{6}{|l|}{ Local scale models } \\
\hline year + wetland density & 4 & 25.6 & 0 & 0.83 & 1 \\
\hline year & 3 & 28.8 & 3.2 & 0.17 & 2 \\
\hline wetland density & 3 & 36.6 & 11.0 & 0.003 & 3 \\
\hline \multicolumn{6}{|l|}{ Regional scale models } \\
\hline wetland density & 3 & -10.6 & 0 & 0.46 & 1 \\
\hline year + wetland density & 4 & -6.9 & 0.8 & 0.38 & 2 \\
\hline year & 3 & -10.0 & 0.7 & 0.33 & 3 \\
\hline
\end{tabular}

Scaup (Aythya affinis) decreased from highs of $25 \%$ to only $12 \%$ of wetlands by 2003 . In contrast, occurrence of Common Goldeneye increased and stabilized, expanding from $1 \%$ to $5 \%$ of wetlands, and Bufflehead from $6 \%$ to $9 \%$ with rapid increases between 1989 and 1995 (Fig. 5). Likewise, Common Goldeneye and Bufflehead were the only species that displayed multiyear trends of increasing density during the study period (Fig. 5).

\section{DISCUSSION}

Occupancy of nest boxes is often used to evaluate the extent that birds are limited by the availability of natural nesting cavities. Detecting true limitation of nest sites is inherently difficult. Locating natural cavity nests can be challenging in some habitat types (e.g., Vaillancourt et al. 2009), population density can be colimited by other factors, e.g., intraspecific competition for food, birds can switch from 
Table 3. Model-averaged parameter estimates and unconditional standard error modeling densities of Common Goldeneye (Bucephala clangula) and Bufflehead (Bucephala albeola) nesting pairs for local and regional scales. $\mathrm{SE}=$ standard error.

\begin{tabular}{|c|c|c|c|c|c|c|}
\hline \multirow[t]{2}{*}{ Model } & \multicolumn{2}{|c|}{ Intercept } & \multicolumn{2}{|c|}{ Year } & \multicolumn{2}{|c|}{$\begin{array}{l}\text { Wetland } \\
\text { density }\end{array}$} \\
\hline & $\beta$ & SE & $\beta$ & SE & $\beta$ & SE \\
\hline \multicolumn{7}{|c|}{ Bufflehead } \\
\hline Local & -478.75 & 121.10 & 0.241 & 0.060 & 0.141 & 0.064 \\
\hline Regional & -5.38 & 11.11 & 0.005 & 0.008 & -0.027 & 0.027 \\
\hline \multicolumn{7}{|c|}{ Common Goldeneye } \\
\hline Local & -248.96 & 103.94 & 0.130 & 0.049 & 0.091 & 0.055 \\
\hline Regional & -6.36 & 12.35 & 0.008 & 0.009 & 0.076 & 0.031 \\
\hline
\end{tabular}

occupying natural nesting sites to artificial boxes (e.g., Gauthier and Smith 1987), or nest box deployment can coincide with other larger scale, sometimes continental, factors that dictate population sizes. Few studies have attempted to demonstrate using experimentation the connection between various measures of breeding activity, the availability of nest boxes, and whether nest box deployment influence population size (Savard 1988, Newton 1994, Pöysä and Pöysä 2002).

We examined evidence of nest site limitation for cavity-nesting ducks using a single-stage cluster design where select clusters of boxes were systematically closed while other clusters remained open. We predicted that closure of boxes would not influence occupancy of wetlands by pairs as adult Common Goldeneye and Bufflehead display high levels of nest site fidelity (e.g., Savard and Eadie 1989, Gauthier 1990) and birds were expected to occupy wetlands where they had nested previously, at least early in the season, prior to searching for alternate nesting sites elsewhere. By contrast, we expected higher numbers of broods in clusters of wetlands where boxes were open compared with clusters with closed boxes, and perhaps larger brood sizes. Larger broods might result if the greater interior space offered by boxes, compared with natural cavities, accommodated larger clutches (Evans et al. 2002), or because of other factors such as delayed nesting resulting in smaller clutches, increased partial clutch predation, or higher duckling mortality. Larger broods might also be a product of intraspecific nest parasitism, which can be common in Bucephala. Females from wetlands where nests were closed could have sought out wetlands where boxes were still open and parasitized these nests.

Consistent with our predictions, closure of nest boxes did not influence occupancy of wetlands by pairs of adult Common Goldeneye and Bufflehead in 2004. However, nest box closure strongly reduced numbers of Common Goldeneye and Bufflehead broods and brood sizes. Brood sizes from wetland clusters with open nest boxes in 2004 were similar to broods documented during July surveys in eight years between 1989-2003 (mean \pm $\mathrm{SE}=$ Common Goldeneye $6.73 \pm 0.43$ chicks, Bufflehead $=5.99 \pm 0.19$ chicks; R. Corrigan, unpublished data) suggesting that larger broods on these clusters were not a product of increased levels of nest parasitism during the experiment. The lack of differences in habitat characteristics between wetland clusters with open vs. closed nest boxes supports our conclusion that differences in numbers of broods and brood sizes arose directly from our manipulation. Nest box occupancy rates by Common Goldeneye and Bufflehead returned to premanipulation levels in 2005 , when previously 
Fig. 5. Temporal patterns in the percent occurrence and density (Number $/ \mathrm{km}^{2}$ ) of Common Goldeneye (Bucephala clangula) and Bufflehead (Bucephala albeola) and six other species of waterfowl between 1989 to 2004 in the Buffalo Lake Moraine. Data are based on biannual surveys of 1275 - 1444 wetlands between 1989 and 2003 (percent occurrence) and 1989 to 2004 (density).
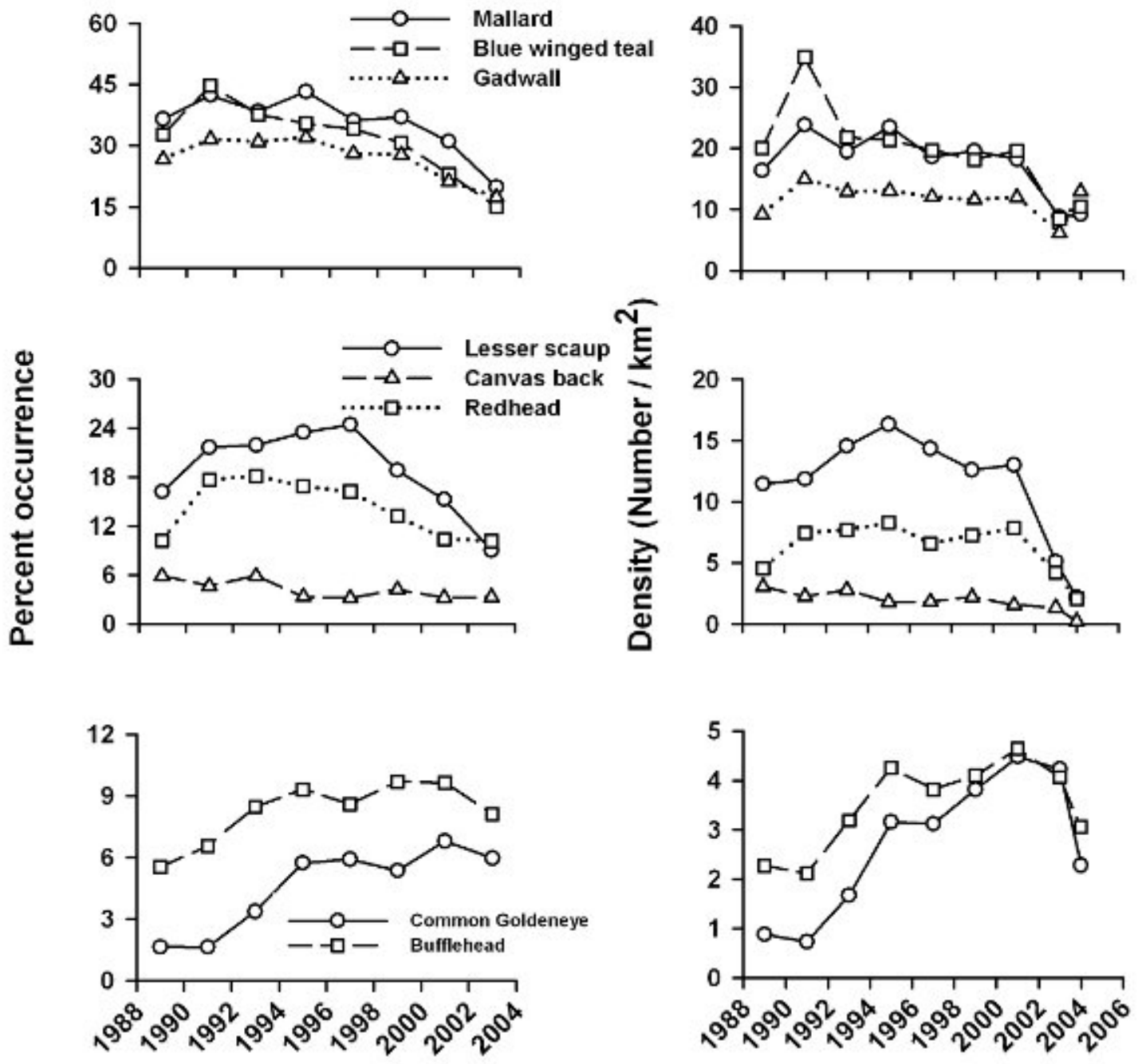
closed nest boxes were reopened, suggesting that birds barred from boxes in 2004 returned in 2005 , or that new individuals readily found vacant boxes in 2005 .

As predicted, responses to nest box closure were more pronounced for Common Goldeneye compared with Bufflehead, suggesting that populations of the larger body size of Common Goldeneye may be more strongly limited by available nest sites. Deployment of nest boxes has been shown to establish breeding populations of Common Goldeneye in areas where the species was present but not reproducing (e.g., Coulter 1979, Dennis and Dow 1984). A consistently lower occupancy rate of nest boxes for Bufflehead relative to Common Goldeneye suggests that more natural cavities are available for Bufflehead on the Buffalo Lake Moraine. Because of their smaller size, Bufflehead are able to nest in smaller, younger trees that are generally more available on the landscape and in smaller cavities (Gauthier and Smith 1987).

In a study of cavity-nesting birds in the boreal mixed-wood forest of northern Alberta and Saskatchewan, Cooke (2009) found 317 avian cavities including one Bufflehead nest located in a Northern Flicker (Colaptes auratus) excavation, and three Common Goldeneye nests and two Bufflehead nests located in Pileated Woodpecker (Dryocopus pileatus) cavities. Neither Common Goldeneye nor Bufflehead used cavities made by smaller woodpeckers, even though Yellow-bellied Sapsucker (Sphyrapicus varius) excavated over $60 \%$ of all available cavities. Cooke (2009) found that Northern Flickers typically excavated dead Populus stems with a diameter at breast height $\geq 21.5$ $\mathrm{cm}$. Pileated Woodpeckers excavated larger, live aspens (diameter at breast height $\geq 33.4 \mathrm{~cm}$ ). Hogg et al. (2005) reported that the diameter at breast height of 12 parkland stands of aspen of 40 to 80 years of age averaged $16.1 \mathrm{~cm}$ (range $=12$ to 21 $\mathrm{cm})$. Based on preferences of Northern Flicker and especially of Pileated Woodpecker, appropriate nest trees for these key excavators, and thus for Bucephala species, are likely uncommon on the Buffalo Lake Moraine.

Lower occupancy of nest boxes by Bufflehead compared with Common Goldeneye may also reflect differences in the outcome of competition with European Starling (Aitken and Martin 2004) that can cause egg mortality as they usurp boxes (Evans et al. 2002). Starlings on the Buffalo Lake
Moraine appeared to prefer small boxes designed for Bufflehead and occupied between $18 \%$ to $47 \%$, even after 1992 when European Starlings annually occupied only $<9 \%$ of the larger boxes designed for Common Goldeneye. In spring, European Starlings arrive on Buffalo Lake Moraine one to three weeks before Bufflehead. They are highly aggressive following egg laying and appear able to repel invaders including Bufflehead, from small but not large nest boxes (Potter 2004).

Large and small nest boxes were often installed as pairs on the same tree for ease of monitoring and because large diameter trees were uncommon. Both Common Goldeneye and Bufflehead are strongly territorial through brood production (Savard 1984, Gauthier and Smith 1987), and thus aggression by Common Goldeneye and Bufflehead might prevent females of the other species from using boxes, as well as exclude other waterfowl from wetlands. In May-June 2004, in 42 hours of observation of eight wetlands, drakes of both species displayed modest levels of aggression (117 interactions species for Common Goldeneye and 91 for Bufflehead). Common Goldeneye males displayed aggression toward nine different species and Bufflehead toward eight, with both Bucephala focusing on intraspecific aggression $(43.6 \%$ of interactions in Common Goldeneye, $49.5 \%$ in Bufflehead). However, Common Goldeneye was much more likely to initiate aggression toward the smaller Bufflehead (41.0\% of all interactions) than Bufflehead toward Common Goldeneye (26.4\% of all interactions). Male agonistic behavior may have contributed to lower use of wetlands with nest boxes and boxes themselves by Bufflehead than by Common Goldeneye. Mutual avoidance by females later in the season is suggested by the fact that during eight annual surveys conducted in July between 1991 and 2003 , an average of only $10.6 \%( \pm 2.0 \mathrm{SE}, \mathrm{n}=8$ to 41 ) of Common Goldeneye broods and $11.4 \%$ $( \pm 2.4, \mathrm{n}=21$ to 39$)$ of Bufflehead broods were observed on wetlands where the other species was present. Despite the fact that both Bucephala species displayed aggression toward a variety of other waterfowl, multivariate analyses comparing species composition for pairs ( $n=412$ wetlands $)$ and broods ( $n=89$ wetlands) of 15 species of birds on the Buffalo Lake Moraine between 1989 to 2003 showed no change in community structure that could be attributed to the presence of greater numbers of Common Goldeneye and Bufflehead (Corrigan 2007). Recall that overall these two species still remained uncommon, each occurring 
on $<10 \%$ of all wetlands on the Buffalo Lake Moraine (Fig. 5).

Numerous studies have shown that clutch size of Common Goldeneye is variable with females typically producing 7.4 to 10.3 eggs per nest (Eadie et al. 1995). We found that average clutch size of Common Goldeneye in the Buffalo Lake Moraine in 2004 was $>14 \%$ higher than other reported values, which may reflect a high background level of brood parasitism in a landscape where nest sites are limited. However, clutch sizes of Common Goldeneye and Bufflehead from wetlands in 2004 where nest boxes had remained open (mean $\pm \mathrm{SE}$ : Common Goldeneye $=12.4 \pm 0.5$, Bufflehead $=4.8$ $\pm 0.6)$ did not differ from that in 2005 when all nest boxes were open (Common Goldeneye $=11.6 \pm 0.5$, Bufflehead $=4.5 \pm 0.4$ ) and thus available nest sites doubled. Therefore, our experimental results did not simply reflect increased rates of brood parasitism with nest box closures, which is consistent with across year comparisons of brood size. Some researchers, e.g., Evans et al. (2002), have proposed that deployment of nest boxes and subsequent competition and nest parasitism might create population sinks for cavity nesting waterfowl. Our study indicates that nest parasitism may have been common for Common Goldeneye and Bufflehead on the Buffalo lake Moraine but we have no evidence that it was affecting population growth.

A major constraint of our single year manipulation was that it precluded establishing definitive linkages between changes in the availability of nest boxes and population size. Observed reductions in numbers of broods and brood sizes in 2004 because of nest box closure were not accompanied by estimates of population size on the Buffalo Lake Moraine. Rigorous examinations of linkages between availability of nesting sites and population size require substantive experimental designs where the manipulation occurs across large spatial scales and over multiple years, and have been rarely completed (but see Pöysä and Pöysä 2002). Our study provides indirect evidence that nest box deployment influences population sizes of Bufflehead and Common Goldeneye by demonstrating (1) 3- to 10-fold reductions in numbers of broods and brood sizes because of nest box closure, (2) increases in occurrence and density over a 16-year period coinciding with nest box deployment, and (3) local increases in populations of the two species on Buffalo Lake Moraine that were not simple manifestations of increases in the size of regional populations. That the occurrence and density of Common Goldeneye and Bufflehead in the moraine tended to increase across the study period, contrary to nearly all other waterfowl and wetland birds surveyed, is further evidence that nest boxes were attracting pairs and supporting breeding of Bucephala species even in the face of a general decline of habitat quality for waterfowl locally and perhaps regionally (Corrigan 2007).

The Alberta Conservation Association produces nest boxes used on the Buffalo Lake Moraine which are then deployed and maintained by volunteers. Boxes are inexpensive to construct (Can\$15) and last $10-15$ years. The program offers a cost effective means of conserving local populations of two waterfowl species, with no indication that the program negatively affects coexisting ducks and waterbirds (Corrigan 2007). Protection of existing pond-side forest stands, including dead and dying trees, augmented by the planting of aspen, represents a long-term transition from nesting cavities provided by artificial boxes to cavities produced by natural forest processes.

Responses to this article can be read online at: http://www.ace-eco.org/vol6/iss 1/artl/responses/

\section{Acknowledgments:}

We thank Andy Murphy, Jim Potter, Velma Hudson, Dave Park, and Doug Manzer, Stephen Hamilton, Laura Hamilton, and Cam Stevens for providing field and technical assistance and discussions. We also thank Marc-André Villard, editorial staff, and the three anonymous reviewers for their valuable comments and perspectives which improved several aspects of the manuscript. Funding and support was provided by the Alberta North American Waterfowl Management Plan Biodiversity fund, Alberta Conservation Association, Ducks Unlimited Canada, and the University of Alberta.

\section{LITERATURE CITED}

Allen, J. 1989. Pair and brood surveys on the NAWMP Alberta First Step Project, Buffalo Lake Moraine. Internal report, Alberta Fish and Wildlife Division, Edmonton, Alberta, Canada. 
Aitken, K. E. H., and K. Martin. 2004. Nest cavity availability and selection in aspen-conifer groves in a grassland landscape. Canadian Journal Forest Research 34:2099-2109. doi:10.1139/x04-086

Bailey, A. W., and R. A. Wroe. 1974. Aspen invasion in a portion of the Alberta Parklands. Journal of Range Management 27:263-266. doi:10 $\underline{.2307 / 3896819}$

Batt, B. D. J., M. G. Anderson, C. D. Anderson, and F. D. Caswell. 1989. Use of prairie potholes by North American ducks. Pages 204-227 in A. Van der Valk, editor. Northern prairie wetlands. Iowa State University Press, Ames, Iowa, USA.

Bellrose, F. C. 1980. Ducks, geese, and swans of North America. Stackpole Books, Harrisburg, Pennsylvania, USA.

Bjorge, R. 2003. Central parkland native vegetation inventory project. Internal report, Alberta Sustainable Resource Development, Red Deer, Alberta, Canada.

Bolton, M., R. Medeiros, B. Hothersall, and A. Campos. 2004. The use of artificial breeding chambers as a conservation measure for cavitynesting procellariiform seabirds: a case study of the Madeiran storm petrel (Oceanodroma castro). Biological Conservation 116:73-80. doi:10.1016/S 0006-3207(03)00178-2

Burnham, K.P., and D. R. Anderson. 2002. Model selection and multimodel inference. SpringerVerlag, New York, New York, USA.

Brightsmith, D. J. 2005. Competition, predation and nest niche shifts among tropical cavity nesters: ecological evidence. Journal of Avian Biology 36:74-83. doi:10.1111/j.0908-8857.2005.03311.x

Cooke, H. A. 2009. Do aggregated harvests with structural retention conserve cavity users in old forest in the boreal plain? Dissertation. University of Alberta, Edmonton, Alberta, Canada.

Corrigan, R. 2007. Effectiveness of nest boxes in influencing population trends for Common Goldeneye (Bucephala clangula) and Bufflehead (B. albeola) in the Buffalo Lake Moraine. Thesis. University of Alberta, Edmonton, Alberta, Canada.
Coulter, M. W. 1979. An experiment to establish a Common Goldeneye Bucephala clangula population. Wildlife Society Bulletin 7:116-118.

Dahl, T. E. 1990. Wetland losses in the United States 1780's to 1980's. United States Department of the Interior, Fish and Wildlife Service, Washington, D. C., USA.

Dennis, R. H., and H. Dow. 1984. The establishment of a population of goldeneyes Bucephala clangula breeding in Scotland. Bird Study 31:217-222. doi:1 $\underline{0.1080 / 00063658409476844}$

Duckworth, R. A. 2006. Aggressive behaviour affects selection on morphology by influencing settlement patterns in a passerine bird. Proceedings of the Royal Society of London Series B 273:1789-1795. doi:10.1098/rspb.2006.3517

Eadie, J. M., M. L. Mallory, and H. G. Lumsden. 1995. Common Goldeneye (Bucephala clangula). In A. Poole and F. Gill, editors. Birds of North America, Number 170. Academy of Natural Sciences, Philadelphia, Pennsylvania, USA, and American Ornithologists' Union, Washington, D. C., USA.

Evans, M. R., D. B. Lank, W.S. Boyd, and F. Cooke. 2002. A comparison of the characteristics and fate of Barrow's Goldeneye and Bufflehead nests in nest boxes and natural cavities. Condor 104:610-619. doi:10.1650/0010-5422(2002)104[0610:ACOTCA] 2.0.CO;2

García-Navas, V., L. Arroyo, J. J. Sanz, and M. Díaz. 2008. Effect of nest box type on occupancy and breeding biology of tree sparrows Passer montanus in central Spain. Ibis 150:356-364. doi:1 0.1111/j.1474-919X.2008.00799.x

Gauthier, G. 1990. Philopatry, nest site fidelity, and reproductive performance in buffleheads. Auk 107:126-132.

Gauthier, G., and J. N. M. Smith. 1987. Territorial behavior, nest site availability, and breeding density in buffleheads. Journal of Animal Ecology 56:171-184. doi:10.2307/4807

Hayek, L. C., and M. A. Buzas. 1997. Surveying natural populations. Columbia University Press, New York, New York, USA. 
Hogg, E. H., J. P. Brandt, and B. Kochtubadja. 2005. Factors affecting interannual variation in growth of western Canadian aspen forests during 1951-2000. Canadian Journal of Forest Research 35:610-622. doi:10.1139/x04-211

Hood, G. A., and S. E Bailey. 2003. Fire and beaver in the boreal forest grassland transition of Western Canada - a case study from Elk Island National park, Canada. Lutra 46:237-244.

Lindenmayer, D. B., A. Welsh, C. Donnelly, M. Crane, D. Michael, C. Macgregor, L. McBurney, R. Montague-Drake, and P. Gibbons. 2009. Are nest boxes a viable alternative source of cavities for hollow-dependent animals? Long-term monitoring of nest box occupancy, pest use and attrition. Biological Conservation 142:33-42. doi:10.1016/j. biocon.2008.09.026

Mátics, R., L. Bank, S. Varga, A. Klein, and G. Hoffmann. 2008. Interspecific offspring killing in owls. Biological Journal of the Linnean Society 95:488-494. doi:10.1111/j.1095-8312.2008.01064. $\underline{\mathrm{X}}$

Merriam, G. 1978. Changes in aspen parkland habitats bordering Alberta sloughs. Canadian Field-Naturalist 92:109-122.

Murphy, A., J. Potter, and R. Bjorge. 2004. Waterfowl pair and brood surveys; Buffalo Lake Moraine (1989-2003). Conservation series report, Alberta Conservation Association, Red Deer, Alberta, Canada.

Newton, I. 1994. The role of nest sites in limiting the numbers of hole-nesting birds: a review. Biological Conservation 70:265-276. doi:10.1016/ 0006-3207(94)90172-4

Nilsson, J.-E. 2008. A 20-year study of a nest-box breeding bird population with special regard to the pied flycatcher Ficedula hypoleuca. Ornis Svecica 18:52-64.

Potter, J. R. 2004. Cavity nesting waterfowl nest box program summary. Conservation series report, Alberta Conservation Association, Red Deer, Alberta, Canada.

Pöysä, H., and S. Pöysä. 2002. Nest-site limitation and density dependence of reproductive output in the Common Goldeneye Bucephala clangula: implications for the management of cavity nesting birds. Journal of Animal Ecology 39:502-510. doi: 10.1046/j.1365-2664.2002.00726.x

Rosvall, K. A. 2008. Sexual selection on aggressiveness in females: evidence from an experimental test with tree swallows. Animal Behaviour 75:1603-1610. doi:10.1016/j.anbehav.20 07.09.038

Savard, J.-P. L. 1984. Territorial behaviour of Common Goldeneye, Barrow's Goldeneye and Bufflehead in areas of sympatry. Ornis Scandinavia 15:211-216. doi:10.2307/3675929

Savard, J.-P. L. 1988. Use of nest boxes by Barrow's goldeneyes: nesting success and effect on the breeding population. Wildlife Society Bulletin 16:125-132.

Savard, J.-P. L., and J. M. Eadie. 1989. Survival and breeding philopatry in Barrow's and Common Goldeneyes. Condor 91:198-203. doi:10.2307/1368 $\underline{163}$

Savard, J.-P. L., and M. Robert. 2007. Use of nest boxes by goldeneyes in eastern North America. Wilson Journal of Ornithology 119:28-34. doi:10.1 $\underline{676 / 05-162.1}$

SPSS. 2007. SPSS statistical software - Version 7. SPSS Inc., Chicago, Illinois, USA.

Stavne, R.B. 2005. Effects of cattle grazing on breeding wetland birds in the Aspen Parkland of Alberta. Thesis, University of Alberta, Edmonton, Alberta, Canada

Stewart, R. E., and H. A. Kantrud. 1971. Classification of natural ponds and lakes in the glaciated prairie region. Fish and Wildlife Service Resource Publication 92, United States Department of Interior, Washington, D.C., USA.

Strong W. L., and K. R. Leggat. 1992. Ecoregions of Alberta. Alberta Forestry, Lands and Wildlife, Land Information Services Division Publication T/244, Edmonton, Alberta, Canada.

United States Fish and Wildlife Service, and Canadian Wildlife Service. 1987. Standard operating procedures for aerial waterfowl breeding ground population and habitat surveys in North 
America. United States Department of Interior, Fish and Wildlife Service, Washington, D.C., USA, and Environment Canada, Canadian Wildlife Service, Ottawa, Ontario, Canada.

Vaillancourt, M.-A., P. Drapeau, M. Robert, and S. Gauthier. 2009. Origin and availability of large cavities for Barrow's Common Goldeneye (Bucephala islandica), a species at risk inhabiting the eastern Canadian boreal forest. Avian Conservation and Ecology - Écologie et conservation des oiseaux 4(1): 6. [online] URL: http://www.ace-eco.org/vol4/iss1/art6/.

Wayland, M., and D. K. McNicol. 1994. Movements and survival of Common Goldeneye broods near Sudbury, Ontario, Canada. Canadian Journal Zoology 72:1252-1259. doi:10.1139/z94-167 